\title{
ASPECTS OF THE REPRODUCTIVE BIOLOGY OF THE SHORTFIN MAKO, Isurus oxyrinchus (ELASMOBRANCHII LAMNIDAE), IN THE SOUTHEASTERN REGION OF BRAZIL
}

\author{
COSTA, F. E. S., ${ }^{1}$ BRAGA, F. M. S., ${ }^{2}$ ARFELLI, C. A. ${ }^{3}$ and AMORIM, A. F. ${ }^{3}$ \\ This paper is part of the Master of Science Dissertation of Fábio E. S. Costa, \\ of the Instituto de Biociências, Unesp, Rio Claro \\ 'UEMS, Rodovia Dourados - Itahum, km 12, C.P. 351 79.8-4-970, Dourados, MS, Brazil \\ ${ }^{2}$ Unesp/Caunesp, C.P. 199, CEP 13506-900, Rio Claro, SP, Brazil \\ ${ }^{3}$ Instituto de Pesca, Divisão de Pesca Marítima, CEP 11030-906, Santos, SP, Brazil \\ Correspondence to: Fábio Edir dos Santos Costa, UEMS, Rodovia Dourados - Itahum, km 12, \\ C.P. 351 79.8-4-970, Dourados, MS, Brazil, e-mail: fabio@uems.br \\ Received December 12, 2000 - Accepted August 14, 2001 - Distributed May 31, 2002
}

(With 6 figures)

\begin{abstract}
Uteri from four pregnant females and two newborn of shortfin mako, Isurus oxyrinchus, were collected in the southeastern region of Brazil, during September, October, and November of 1993 and 1994. All embryos were near-term with developing dentition and inner organs. Total length ranged from 64.5 to $72.0 \mathrm{~cm}$, and the maximum number of embryos observed in a litter was 20 . These observations further confirmed oophagy as a form of nutrition in this species, and its periodicity. The presence of teeth in the embryos' stomachs suggest that tooth replacement begins in the uterine phase.
\end{abstract}

Key words: Elasmobranchii Lamnidae, Isurus, reproduction, biometry.

\section{RESUMO}

\section{Aspectos da biologia reprodutiva do anequim Isurus oxyrinchus} (Elasmobranchii Lamnidae) na região Sudeste do Brasil

Quatro úteros provenientes de quatro fêmeas prenhas e dois indivíduos recém-nascidos de anequim, Isurus oxyrinchus, foram coletados na região Sudeste do Brasil durante os meses de setembro a novembro de 1993 e 1994. Todos os embriões estavam bem desenvolvidos, próximos ao estágio de nascimento, apresentando a dentição e órgãos internos bastante desenvolvidos. O comprimento total desses embriões variou entre 64,5 e $72,0 \mathrm{~cm}$, e o maior número de embriões observado no interior de uma única fêmea foi 20. As observações aqui realizadas confirmam a oofagia como forma de nutrição dos embriões dessa espécie e sua periodicidade. A presença de dentes no estômago dos embriões sugere que a substituição dos dentes se inicia na fase uterina.

Palavras-chave: Elasmobranchii Lamnidae, Isurus, reprodução, biometria.

\section{INTRODUCTION}

The reproductive cycles of large elasmobranches are generally difficult to describe during certain stages of gestation, because individuals make themselves unavailable as a result of the formation of shoals and groupings in some regions, and because they present a migratory behavior
(Holden, 1974). The most recent classification which is also the most usual, was proposed by Otake (1990) in which both morphologic characteristics and phylogenic data were analized. For the shortfin mako, Isurus oxyrinchus Rafinesque, according to Otake's (1990) observations, the classification of the reproductive mode of this species, as well as all members of the Lamnoid order, is 
that of an oophagous species with the uterus containing no compartments. In this case, the embryo obtains nutrients from ovules or eggs produced through the mother's continuous ovulation during gestation and sometimes through the ingestion of embryos developing from these eggs. This group is quite specialized in the forms of nutrient transportation, including physiological adaptations for the production of ovules and continuous ovulation. Within the type of uterus without compartments, the oophagous forms are the derived forms, while the lecitotrophic forms which present the yolk sac throughout embryonic development, could be more primitive.

Oophagy in the embryonic phase has been well documented for the Lamnoid order, having been described for 9 of the 16 species. Another form of nutrition of the embryo which is characteristic to this order is intra-uterine cannibalism, also known as embryophagy or adelphophagy, but this was only confirmed in one species, Odontaspis taurus Rafinesque. These forms of embryo nutrition have shown to be efficient for the growth and production of large individuals at birth (Gilmore, 1990). In I. oxyrinchus, oophagy in the embryonic phase was cited by Cadenat (1950), Stevens (1983), Uchida et al. (1987), and Gilmore (1993), and the first detailed description of oophagy was put forward by Swenander (apud Gilmore, 1993) for Lamna nasus Bonaterre.

The development of functional dentition in lamnoid embryos can be a sign of their capacity to consume other embryos inside the uterus. Erect and functional teeth were described for $O$. taurus embryos as being $40 \mathrm{~cm}$ long (Gilmore et al., 1983; Hamlett, 1983). The embryonic dentition of Alopias pelagicus Nakamura, Alopias superciliosus Lowe, Charcharodon charcharias Linnaeus I. oxyrinchus, Isurus paucus Guitart, and Pseudocarcharias kamoharai Matsubara, is believed not to be functional and consists of slanting teeth covered by a membrane (Sanzo, 1912; Fujita, 1981; Gilmore, 1983; Gilmore et al., 1983; Uchida et al., 1987).

Lamnoids usually present a birth size, ranging between 67 and $110 \mathrm{~cm}$; an exception is Cetorhinus maximus Gunnerus, where the largest newborn observed was $170 \mathrm{~cm}$ in length. The large size of these individuals at birth is an important form of defense against predation (Gilmore, 1990). Castro (1983) and Stevens (1983), established some parameters through the study of reproductive aspects of , I. oxyrinchus, as follows: gestation period 12 months; maximum length $-364 \mathrm{~cm}$; maximum size at birth $-80 \mathrm{~cm}$; average size at birth -22 $\mathrm{cm}$; average length of female maturation $-280 \mathrm{~cm}$; average length of male maturation $-195 \mathrm{~cm}$; age at which the female matures - 7 years; and maximum number of embryos in the uterus -16 .

Corroborating these values, Bass et al. (1975) suggested that males must mature at approximately $200 \mathrm{~cm}$ and females at a size larger than this. In opposition to these values, Gubanov (1978) suggested that females reach sexual maturity at approximately $180 \mathrm{~cm}$, supporting this statement by his observations of the smallest female captured which presented scars, indicating occurrence of copulation. On analysis of two embryos (1 male and 1 female) from a female with a total length of 343 $\mathrm{cm}$, Stevens (1983) found neither umbilical cord scars in the embryos, nor the presence of placenta or uterine compartments in the analysis of the uterus, suggesting that the birth size of I. oxyrinchus embryos is approximately $70 \mathrm{~cm}$ total length, thus further corroborating Bass et al. (1975) data. Consequently, it can be observed that although information exists on the reproduction of I. oxyrinchus, it is often controversial or presents lacunae at various points. Thus, the main goal of this work is to contribute to the knowledge of the reproductive biology of the species both by adding new information and corroborating existing conjectures.

\section{MATERIAL AND METHODS}

Four shortfin mako uteri with embryos were collected, from tuna fishing boats based in Santos, State of São Paulo (Brazil). The uteri were collected between September 15 and November 15 in 1993 and 1994. Two newborn individuals were also collected and captured with a long line by these boats. The total fishing area of these boats during the period of capture was Lat. $20^{\circ}-28^{\circ} 35^{\prime} \mathrm{S} /$ Long. $38^{\circ}-45^{\circ} 50^{\prime} \mathrm{W}$.

Both embryos and neonates were analyzed, the general characters of their developmental stage were observed, and morphometric data were recorded according to Bass (1973) and Compagno (1984), as well as the sex ratio among the embryos. Morphometric data gathered from the individuals are shown in Fig. 1. The data obtained were grouped according to sex, so as to verify the existence of significant differences in measurements between 
them. When there were distinct variations, the Aspin-Welsh Test (Berhens-Fisher theorem) was applied, which tests two sampling averages with distinct variations. In both cases, a 5\% level of significance was adopted (Sokal \& Rohlf, 1996).

The teeth found inside the stomachs of part of the analyzed embryos were measured (distance from base to apex), with the use of a micrometric ocular under a stereomicroscope (zoom 10x), and compared to the dentition of the dental arch of one of the embryos.

In order to compare the collected data, some information on, I. oxyrinchus' embryos also captured by tuna fishing boats based in Santos during the period between December 1989 and February 1990, was also used.
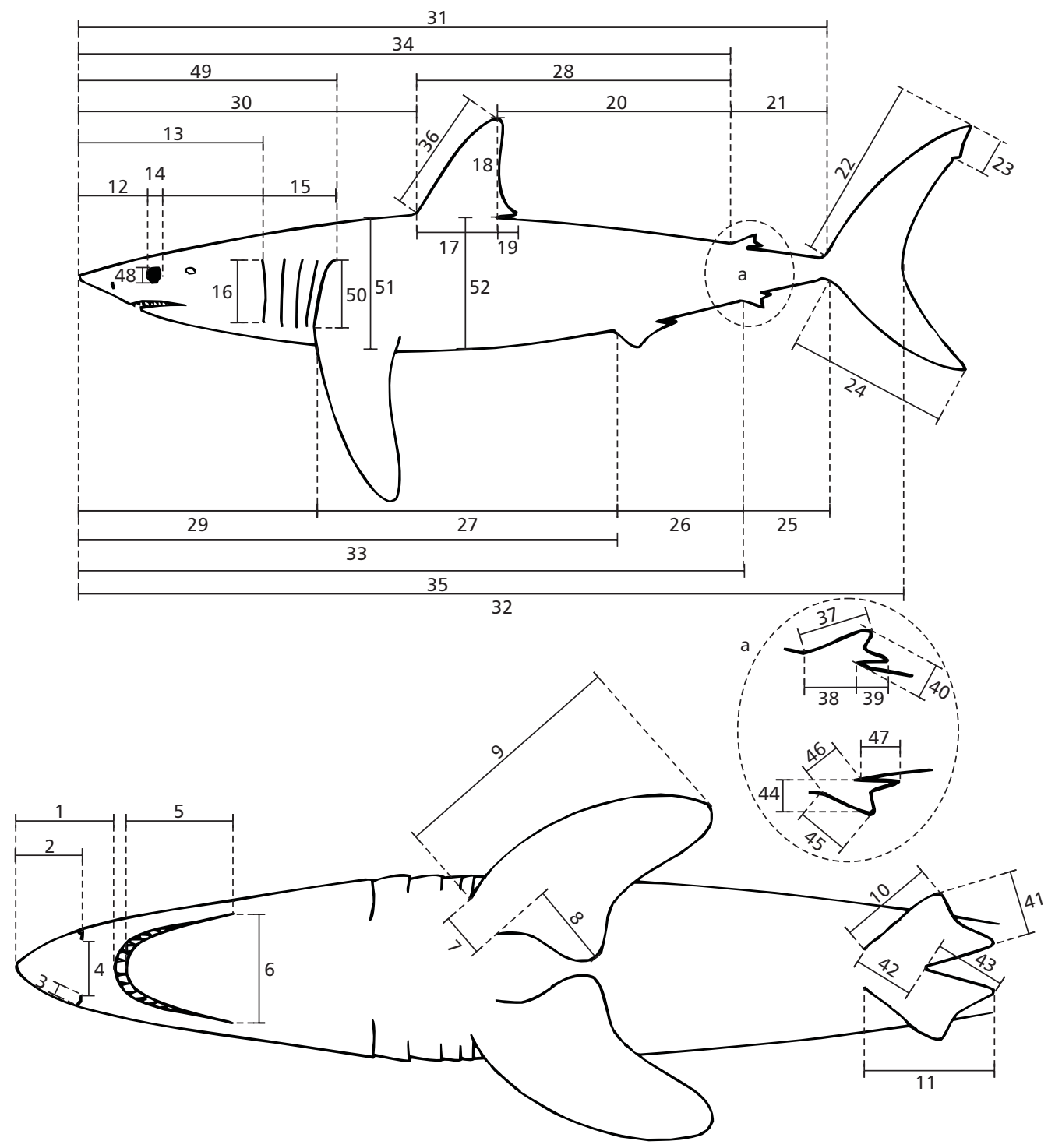

Fig. 1 - Morphometric data used in the biometry of embryos and newborn of Isurus oxyrinchus. 


\section{RESULTS}

All embryos coming from the analyzed uteri presented an advanced stage of development, close to the time of birth. Lorenzini ampullae in addition to well-defined lateral lines, and the absence of spiracles and yolk sac were observed in all cases (Table 1).

On analysis of the first uterus, access was limited to one embryo only. The embryo presented an advanced stage of development, with its dentition quite developed, internal organs well-formed, and an empty stomach.

The embryos from the second uterus analyzed were in a stage of development slightly below that of the previous ones, as their average size was smaller and their spiral valves were not totally formed.

All individuals from the third uterus presented an advanced stage of development. In all embryos of this uterus, the caudal flipper presented a heterocercal shape, differing in shape from that of the adult, whose both lobes are practically identical (Fig. 2A).

Inside the stomachs of all individuals coming from the second and third uteri, the presence of a large quantity of vitellus fluid could be observed (full stomach), with a greenish color.

Amid this vitellus, in all individuals, teeth were found either connected to each other or separate, but less developed than those in the dental arch of the embryos. Those teeth were collected and analyzed under a stereomicroscope, and then measured and distributed in size classes (Figs. 3 and 4).

During the period from December 1989 to February 1990 two other uteri were collected (numbers 4 and 5). The total length of the embryos from the $4^{\text {th }}$ uterus ranged between 52 and $67 \mathrm{~cm}$, and from uterus number 5 ranged between 58.4 and $61.9 \mathrm{~cm}$.

During the whole study period, uteri of mature females were examined throughout the year (more than 20). However, only during Spring and the beginning of Summer (September to February) were pregnant females found in the studied region. The absence of pregnant females in the initial stage of gestation in catches in the studied area suggests that they are not present in the area covered by the tuna fishing fleet in the southeast and south of Brazil, or that they are not vulnerable to the fishing gear.

During the same trip in which the third uterus was collected (first fortnight of November 1994), two newborn individuals of $I$. oxyrinchus were captured with paternoster line by the same fishing boat. They were close in size to the embryos: 66.4 and $69.3 \mathrm{~cm}$ of total length (Fig. 2B). But two evident characteristics differentiated them: the newborns had a much more rigid body musculature than did the embryos, and their teeth were already exposed and protruding from the mouth, similar to the adult configuration, and apparently functional, while the embryos' teeth slanted towards the interior of the mouth (Figs. 5 and 6).

The results obtained from biometric analysis of the embryos (by sex) and newborns are represented in total length percentage in Table 2. The analysis of male and female averages showed that generally the measurements yielded by embryo biometry were similar for both sexes, except for the length of the lower lobe of the caudal flipper, the $5^{\text {th }}$ branchial slit lenghth, and the height of the trunk at the pectoral fin (Table $2-*$ ).

TABLE 1

Uteri data collected.

\begin{tabular}{|c|c|c|c|c|}
\hline $\begin{array}{c}\text { Uterus } \\
\text { number }\end{array}$ & $\begin{array}{c}\text { Total numbert of } \\
\text { embryos }\end{array}$ & $\begin{array}{c}\text { Number of embryos } \\
\text { analyzed } \\
\text { male/female }\end{array}$ & $\begin{array}{c}\text { Total length } \\
\text { male embryos } \\
\text { average/min./max. }\end{array}$ & $\begin{array}{c}\text { Total length } \\
\text { female embryos } \\
\text { average/min./max. }\end{array}$ \\
\hline 1 & Unknown & $0 / 1$ & - & 71.2 \\
\hline 2 & 13 & $6 / 4$ & $68.28 / 66.5 / 70.4$ & $66.17 / 64.5 / 69.1$ \\
\hline 3 & 15 & $6 / 9$ & $70.1 / 67.7 / 71.6$ & $69.7 / 64.5 / 69.1$ \\
\hline 4 & 20 & $10 / 10$ & Unknown & Unknown \\
\hline 5 & 3 & $2 / 1$ & $59.55 / 58.4 / 60.7$ & 61.9 \\
\hline
\end{tabular}

* Data in centimeters $(\mathrm{cm})$ 


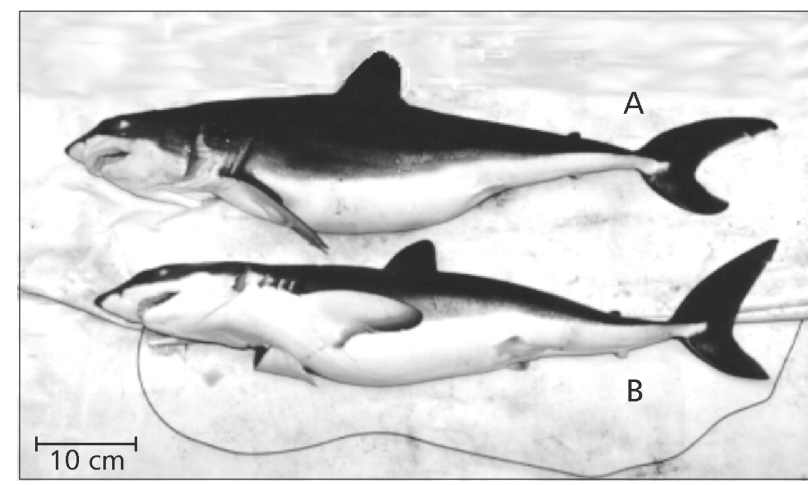

Fig. 2 - Samples of Isurus oxyrinchus. A: embrio, B: newborn.

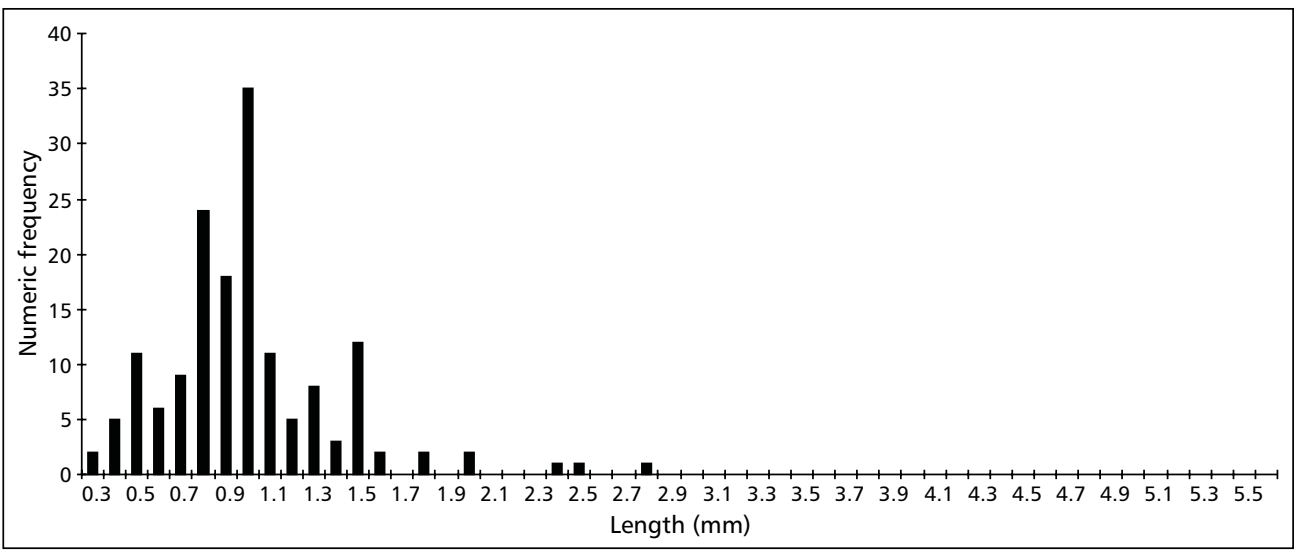

Fig. 3 - Frequency of distribution of the classes of teeth length of Isurus oxyrinchus based on teeth found in embryo.

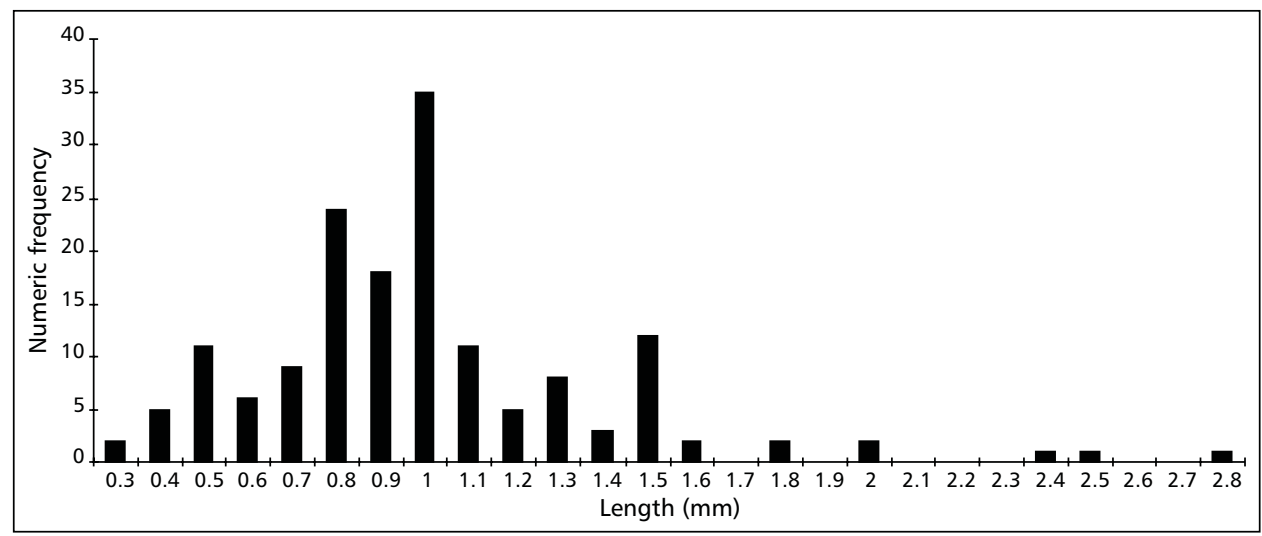

Fig. 4 - Frequency of distribution of the classes of teeth length of Isurus oxyrinchus based on teeth from dental arch of one of the embryos analyzed. 


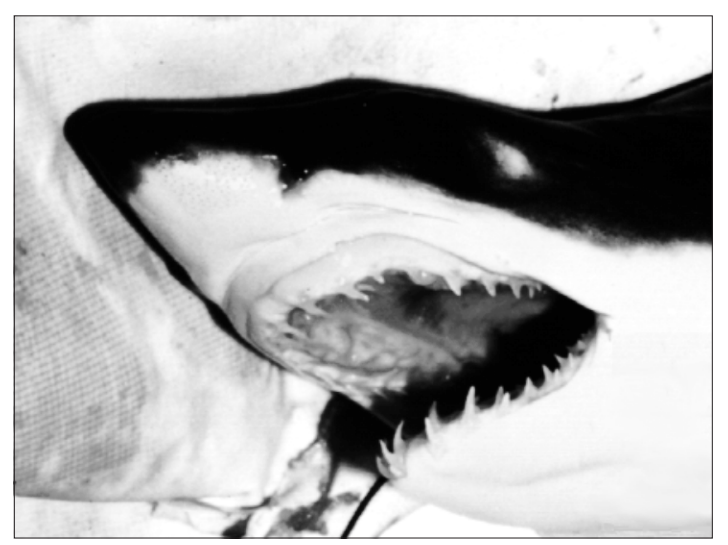

Fig. 5 - Detail of the head of a newborn Isurus oxyrinchus, showing the teeth protruding from the mouth.

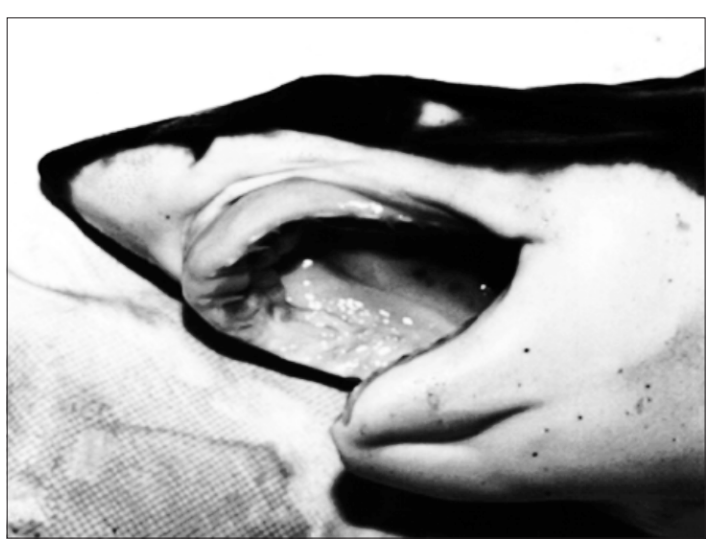

Fig. 6 - Detail of the head of an embryo Isurus oxyrinchus, showing the teeth lying against the gum.

TABLE 2

Percentage related to the total length of the measures taken from the embryos and newborns of Isurus oxyrinchus.

\begin{tabular}{|c|c|c|c|c|c|c|c|c|c|c|c|}
\hline \multirow{2}{*}{$\begin{array}{c}\text { Morphometric } \\
\text { data }\end{array}$} & \multicolumn{4}{|c|}{ Male } & \multicolumn{4}{|c|}{ Female } & \multicolumn{3}{|c|}{ Newborn } \\
\hline & average & $\max$ & $\min$. & s.e. & average & $\max$. & min. & s.e. & average & max. & min. \\
\hline 1 & 5.87 & 7.38 & 4.35 & 1.15 & 5.93 & 7.30 & 4.34 & 0.99 & 6.83 & 6.52 & 7.14 \\
\hline 2 & 5.41 & 6.21 & 4.54 & 0.66 & 5.21 & 6.77 & 4.19 & 0.85 & 5.21 & 4.88 & 5.54 \\
\hline 3 & 0.99 & 1.28 & 0.64 & 0.15 & 1.00 & 1.57 & 0.70 & 0.23 & 1.05 & 0.98 & 1.13 \\
\hline 4 & 4.22 & 5.06 & 3.85 & 0.31 & 4.12 & 4.93 & 3.48 & 0.34 & 4.01 & 3.92 & 4.10 \\
\hline 5 & 6.31 & 7.10 & 5.70 & 0.42 & 6.40 & 6.94 & 5.72 & 0.34 & 6.75 & 6.54 & 6.97 \\
\hline 6 & 8.48 & 9.86 & 6.98 & 0.67 & 8.47 & 9.55 & 7.87 & 0.50 & 8.22 & 7.83 & 8.60 \\
\hline 7 & 5.38 & 6.78 & 4.35 & 0.81 & 5.51 & 6.48 & 4.71 & 0.59 & 5.46 & 5.05 & 5.87 \\
\hline 8 & 8.01 & 14.00 & 3.91 & 4.23 & 9.79 & 13.79 & 3.51 & 4.49 & 14.38 & 13.70 & 15.05 \\
\hline 9 & 16.78 & 18.25 & 14.54 & 0.89 & 17.07 & 18.22 & 16.36 & 0.52 & 17.59 & 17.17 & 18.01 \\
\hline 10 & 4.03 & 4.54 & 3.39 & 0.33 & 3.90 & 4.26 & 3.31 & 0.25 & 4.41 & 4.07 & 4.76 \\
\hline 11 & 6.69 & 7.20 & 5.95 & 0.36 & 6.33 & 7.31 & 5.69 & 0.44 & 7.25 & 7.05 & 7.45 \\
\hline 12 & 6.99 & 7.95 & 6.05 & 0.62 & 7.12 & 7.82 & 6.51 & 0.36 & 7.43 & 7.41 & 7.46 \\
\hline 13 & 21.56 & 22.96 & 19.55 & 0.90 & 21.83 & 22.44 & 20.70 & 0.43 & 21.96 & 21.79 & 22.14 \\
\hline 14 & 2.28 & 2.99 & 1.60 & 0.32 & 3.79 & 22.54 & 2.10 & 5.40 & 2.60 & 2.56 & 2.64 \\
\hline 15 & 7.22 & 7.82 & 6.11 & 0.59 & 7.65 & 8.31 & 7.22 & 0.41 & 0.00 & 0.00 & 0.00 \\
\hline 16 & 8.32 & 10.82 & 7.14 & 0.95 & 7.67 & 8.30 & 7.07 & 0.40 & 7.12 & 6.63 & 7.62 \\
\hline 17 & 8.40 & 9.54 & 7.62 & 0.55 & 8.28 & 8.99 & 7.93 & 0.33 & 8.54 & 8.38 & 8.70 \\
\hline 18 & 7.33 & 8.03 & 6.56 & 0.37 & 7.29 & 8.52 & 6.31 & 0.57 & 8.04 & 7.53 & 8.56 \\
\hline 19 & 1.85 & 2.47 & 1.60 & 0.23 & 1.91 & 2.21 & 1.64 & 0.15 & 1.93 & 1.81 & 2.05 \\
\hline 20 & 24.50 & 25.54 & 22.97 & 0.90 & 25.14 & 25.56 & 23.96 & 0.67 & 0.00 & 0.00 & 0.00 \\
\hline
\end{tabular}


TABLE 2 (Continued)

\begin{tabular}{|c|c|c|c|c|c|c|c|c|c|c|c|}
\hline \multirow{2}{*}{$\begin{array}{c}\text { Morphometric } \\
\text { data }\end{array}$} & \multicolumn{4}{|c|}{ Male } & \multicolumn{4}{|c|}{ Female } & \multicolumn{3}{|c|}{ Newborn } \\
\hline & average & $\max$. & min. & s.e. & average & $\max$. & $\min$. & s.e. & \begin{tabular}{|l|} 
average \\
\end{tabular} & $\max$. & $\min$. \\
\hline 21 & 10.38 & 11.63 & 9.27 & 0.81 & 10.80 & 11.10 & 10.39 & 0.32 & 0.00 & 0.00 & 0.00 \\
\hline 22 & 20.73 & 21.73 & 19.57 & 0.54 & 21.23 & 22.44 & 19.69 & 0.76 & 21.74 & 21.69 & 21.79 \\
\hline 23 & $4.43^{*}$ & 4.85 & 3.76 & 0.31 & $4.69^{*}$ & 5.05 & 4.16 & 0.41 & 0.00 & 0.00 & 0.00 \\
\hline 24 & 13.11 & 14.21 & 11.94 & 0.53 & 13.81 & 15.00 & 12.94 & 0.65 & 14.28 & 13.70 & 14.86 \\
\hline 25 & 9.14 & 9.74 & 8.43 & 0.39 & 9.68 & 9.89 & 9.43 & 0.23 & 0.00 & 0.00 & 0.00 \\
\hline 26 & 15.27 & 17.26 & 13.83 & 1.10 & 14.57 & 16.57 & 12.71 & 1.37 & 0.00 & 0.00 & 0.00 \\
\hline 27 & 31.32 & 33.04 & 29.72 & 1.19 & 30.28 & 33.80 & 26.26 & 2.74 & 0.00 & 0.00 & 0.00 \\
\hline 28 & 32.87 & 33.66 & 32.45 & 0.43 & 33.20 & 34.30 & 32.46 & 0.79 & 0.00 & 0.00 & 0.00 \\
\hline 29 & 26.02 & 31.56 & 24.05 & 1.82 & 27.08 & 29.77 & 25.15 & 1.31 & 27.49 & 27.13 & 27.86 \\
\hline 30 & 37.28 & 38.30 & 35.07 & 0.92 & 37.72 & 38.84 & 36.32 & 0.78 & 38.91 & 38.82 & 39.01 \\
\hline 31 & 79.07 & 79.76 & 77.92 & 0.54 & 78.74 & 80.43 & 77.56 & 0.84 & 80.43 & 79.08 & 81.78 \\
\hline 32 & 87.67 & 90.31 & 85.44 & 1.24 & 87.70 & 89.19 & 85.78 & 0.92 & 89.10 & 88.60 & 89.61 \\
\hline 33 & 56.22 & 59.29 & 53.99 & 2.11 & 56.37 & 57.83 & 55.01 & 0.92 & 56.46 & 55.70 & 57.23 \\
\hline 34 & 70.16 & 71.63 & 68.64 & 1.07 & 70.05 & 71.15 & 68.11 & 0.93 & 71.07 & 69.70 & 72.44 \\
\hline 35 & 70.62 & 72.34 & 68.95 & 1.34 & 70.22 & 71.91 & 68.53 & 1.25 & 72.02 & 71.00 & 73.04 \\
\hline 36 & 10.36 & 10.91 & 10.07 & 0.35 & 10.06 & 10.96 & 8.59 & 0.63 & 10.37 & 10.21 & 10.53 \\
\hline 37 & 2.03 & 2.35 & 1.73 & 0.24 & 2.37 & 3.66 & 1.88 & 0.51 & 2.29 & 2.12 & 2.45 \\
\hline 38 & 1.32 & 1.84 & 1.09 & 0.26 & 1.11 & 1.27 & 0.92 & 0.12 & 1.11 & 1.02 & 1.20 \\
\hline 39 & 1.99 & 2.51 & 1.70 & 0.29 & 1.91 & 2.21 & 1.68 & 0.16 & 2.19 & 2.15 & 2.22 \\
\hline 40 & 1.35 & 1.72 & 0.95 & 0.26 & 1.32 & 1.88 & 1.04 & 0.27 & 1.40 & 1.22 & 1.57 \\
\hline 41 & 2.91 & 4.61 & 1.84 & 0.92 & 2.79 & 5.10 & 1.95 & 0.93 & 4.02 & 3.68 & 4.37 \\
\hline 42 & 4.32 & 5.27 & 3.35 & 0.69 & 4.33 & 4.87 & 3.65 & 0.44 & 4.08 & 3.07 & 5.08 \\
\hline 43 & 4.15 & 5.26 & 0.45 & 1.84 & 4.92 & 5.35 & 3.36 & 0.66 & 5.57 & 5.34 & 5.80 \\
\hline 44 & 1.76 & 2.32 & 1.18 & 0.44 & 1.46 & 1.83 & 1.24 & 0.20 & 1.56 & 1.43 & 1.69 \\
\hline 45 & 2.44 & 3.17 & 2.04 & 0.39 & 2.42 & 2.82 & 2.15 & 0.19 & 2.55 & 2.41 & 2.68 \\
\hline 46 & 1.36 & 1.70 & 1.06 & 0.23 & 1.19 & 1.37 & 1.02 & 0.12 & 1.18 & 1.08 & 1.28 \\
\hline 47 & 2.07 & 2.15 & 1.83 & 0.12 & 1.99 & 2.28 & 1.83 & 0.17 & 2.30 & 2.11 & 2.50 \\
\hline 48 & 2.08 & 2.29 & 1.91 & 0.15 & 2.06 & 2.22 & 1.99 & 0.08 & 2.20 & 2.15 & 2.26 \\
\hline 49 & 29.25 & 33.00 & 26.26 & 2.24 & 28.99 & 30.54 & 23.65 & 2.06 & 30.20 & 29.67 & 30.74 \\
\hline 50 & $7.78^{*}$ & 8.81 & 7.25 & 0.56 & $7.06^{*}$ & 7.63 & 6.52 & 0.37 & 7.37 & 7.06 & 7.68 \\
\hline 51 & $11.86^{*}$ & 12.60 & 10.64 & 0.71 & $10.59^{*}$ & 11.45 & 9.54 & 0.68 & 11.14 & 11.13 & 11.14 \\
\hline 52 & 11.37 & 12.11 & 10.01 & 0.88 & 10.92 & 11.59 & 10.03 & 0.53 & 10.74 & 10.48 & 10.99 \\
\hline
\end{tabular}

\section{DISCUSSION}

The Mako shark, Isurus oxyrinchus, is a coastal and oceanic species distributed in all oceans from the temperate to tropical regions. It is caught regularly year-round off of southern Brazil by the longliners based in Santos, São Paulo, Brazil. The mako shark yield of this fleet ranged from $13 \mathrm{t}$ (1975) to $138 \mathrm{t}$ (1990), and was constituted of individuals presenting between 40 and $250 \mathrm{~cm}$, 
mainly 110 to $130 \mathrm{~cm}$ in pectoral-caudal length (Costa et al., 1996)

With regard to the biological and reproductive parameters of , I. oxyrinchus according to what was observed in embryos from the four uteri collected, it was verified that all were close to birth, as they already presented quite developed dentition and practically formed inner organs with an amplitude of 64.5 to $72.0 \mathrm{~cm}$ of the total length. Stevens (1983) states that the birth size of the young should be approximately $70.0 \mathrm{~cm}$, while Bass et al. (1975) observed a very similar value.

Generally, the bodily proportions of embryos in relation to sex are similar; therefore, the intrauterine development is also considered similar between the sexes.

It is known that uterine fecundity varies between species and that it also can vary between individuals of the same species. Compagno (1984) states that the estimated number of shortfin mako young ready to be born is approximately 4 to 16 per uterus. Bass et al. (1975), in the observations carried out with , I. oxyrinchus, registered an identical finding. These values also agree with those of Pratt \& Casey (1990), who estimated that the average number of embryos ready to be born per uterus ranges between 2 and 16. Nevertheless, the uteri analyzed of , I. oxyrinchus in the southeastern region of Brazil indicate that this number can reach 20 embryos per litter.

Stevens (1983) suggests that for I. oxyrinchus of the region of New South Wales (Australia), the birth of young is likely to occur in November. This date seems in accordance with what was observed in our analysis of the four uteri, but the data of the embryos from December 1989 and from February 1990 show that at least for the area studied, the period for birth of the young may be a little longer, extending from March to July.

Gubanov (1978), studied the reproduction of some species of pelagic sharks of the equatorial zone of the Indian Ocean. In relation to I. oryrinchus, he examined a female in July 1972 which had recently delivered, and in its uterus found remnants of placenta and six umbilical cords fixed to it, indicating placental viviparity for the species. A similar fact was observed by Solov'yev (oral communication in Gubanov, 1978) in December of the same year.

Bigelow \& Schroeder (1948) had already studied part of the reproductive aspects of this species and classified it as ovoviviparous (or, as it is now called, aplacental viviparous), where there is no direct connection between mother and embryo. Gubanov (1978) encountered further contradictory data for other species of pelagic sharks.

The studies and observations made to date have resulted in a consensus that among lamnoid sharks, the reproductive form presented is aplacental viviparity, with the occurrence of oophagy as a form of embryo nutrition. The occurrence of intra-uterine cannibalism as well as oophagy (Otake, 1990; Gilmore, 1993) has been confirmed only for O. taurus.

The reproductive parameters known and accepted for I. oxyrinchus are those proposed by Stevens (1983), Castro (1983), Bass et al. (1975), and Gubanov (1978) which are: period of gestation: 12 months; maximum length: $364 \mathrm{~cm}$; size at birth: $70 \mathrm{~cm}$, approximately; average birth size: $22 \mathrm{~cm}$; average size of female maturation: $280 \mathrm{~cm}$; average size of male maturation: approximately $200 \mathrm{~cm}$; age at which females mature: 7 years; and maximum number of embryos in uterus: 16.

Compagno (1984) states that for I. oxyrinchus, embryo development is of the aplacental viviparous type, with the possibility of occurrence of intrauterine cannibalism. Bass et al. (1975) and Stevens (1983) also failed to observe the formation of placenta or any other similar structure in embryo analysis of this species or any other species of this order (Lamnoid sharks), and likewise suggest that I. oxyrinchus embryos are oophagous.

Through the observations carried out on embryos from four different uteri, besides confirming oophagy as a form of embryo nutrition, it was verified that when vitellus is present in the stomachs, all embryos from the same uterus present stomachs full of vitellus as well. In no case, when comparing embryos from the same uterus, was the presence of vitellus found in only part of the embryos observed; neither was it found in small quantities.

This suggests that the process of ovulation of the mother, i. e., discharging ovocytes to embryos, must occur in cycles, in such a way that a large quantity of ovocytes mature in the ovaries at the same time, and discharged in a single batch. Thus, all embryos present in the uterus have access to a large quantity of vitellus simultaneously. Following ovocite discharge, the ovaries rest for a time while maturing another batch of ovocytes, be released when ready. Consequently, in different pregnant 
females with embryos at similar stages of development, there can be observed embryos both with and without vitellus in their stomachs.

As observed by Gilmore et al. (1983), the embryos coming from the third and fourth uteri also presented large distentions in the abdominal region, caused by ingesting large quantities of vitellus.

Comparing the frequency of distribution of the size of the teeth found in the stomachs of 25 out of 28 embryos with the frequency of distribution of teeth on a normal embryo arch, it was verified that the teeth found were of smaller size. Therefore, it is believed that the teeth present in the stomachs of the individuals were their own, having been swallowed during a replacement process.

Intra-uterine teeth replacement is known for the ray Rhinoptera bonasus Mitchill, in which several dental plates have been found, but in this case they were inside the uteri from which the individuals approaching birth had been removed. It is believed, therefore, that in this species (Bigelow \& Schroeder, 1953; Smith \& Merriner, 1986) teeth replacement occurs in the uterine phase. Similarly to I. oxyrinchus, embryo nutrition of $R$. bonasus takes place through oophagy.

Because teeth were only found in the stomachs of the embryos and no other structure indicated intra-uterine cannibalism, it is believed that these teeth come from the arches of the embryos themselves; as teeth grow, the rows being renewed, occasioning accidental ingestion. This explains the presence of smaller size teeth in the stomachs as compared to the teeth in the embryos' arches, and shows that those teeth must have been swallowed while the embryos were even less developed.

In conclusion, the presence of a large quantity of vitellus in the embryos' stomachs confirms oophagy as the form of nutrition of the young in the maternal uteri. The teeth found in the embryos' stomachs suggests that their replacement in this species begins in the uterine phase as a result of the development process of the dental arch.

The birth period of the species I. oxyrinchus in the southeastern region of Brazil is mainly in Spring (October to December), sometimes stretching till Summer, and the maximum number of embryos observed within the same gestation was 20 individuals.

\section{REFERENCES}

BASS, A. J., 1973, Analysis and description of variation in the proportional dimensions of Scyliorhinid, Carcharhinid and Sphynid Sharks. Investigational Report of Oceanographic Research Institute, Durban, South Africa, 32(1): $28 \mathrm{p}$.

BASS, A. J., D'AUBREY, J. D. \& KISTNASAMY, N., 1975, Sharks of the east coast of Southern Africa. IV. The Families Odontaspidae, Scapanorhynchidae, Isuridae, Setorhinidae, Alopiidae, Orectolobidae and Rhiniodontidae. Investigational Report of Oceanographic Research Institute, Durban, South Africa, 39(1): 102p.

BIGELOW, H. B. \& SCHROEDER, W. C., 1948, Sharks: fish of the Western North Atlantic. Memorial Sears Foundation for Marine Research, pp. 59-576 (Memoir, 1).

BIGELOW, H. B. \& SCHROEDER, W. C., 1953, Fish of the Western North Atlantic: 2. Sawfishes, guitarfishes, skates, rays and chimareoids, Memorial Sears Foundation for Marine Research, 1: 1-558.

CADENAT, J., 1950, Poissons de mer du Sénegal. Initiations Africaines, 3: 345p.

CASTRO, J. I., 1983, The sharks of North American waters. Texas A\&M University Press, College Station, 180p.

COMPAGNO, L. J. V., 1984, FAO species catalogue: sharks of the World: an annoted and illustrated catalogue of shark species known to date. FAO Fisheries Synopsis, 4(1-2): $665 \mathrm{p}$.

COSTA, F. E. S., BRAGA, F. M. S., AMORIM, A. F. \& ARFELLI, C. A., 1996, Fishery analysis on Shortfin Mako, Isurus oxyrinchus, off southeast and south of Brazil (Elasmobranchii: Lamnidae). Arquivos de Ciências do Mar, 30(1-2): 5-12.

FUJITA, K., 1981, Oviphagous embryos of the pseudocarchariid shark, Pseudocarcharias kamoharai, from the central Pacific. Japanese Journal of Ichyology, 28: 37-44.

GILMORE, R. G., 1983, Observations on the embryos of the longfin mako, Isurus paucus, and the bigeye thresher, Alopias superciliosus. COPEIA, pp. 375-382.

GILMORE, R. G., 1990, The reproductive biology of Lamnoid sharks. In: S. H. Gruber (ed.), Discovering sharks. Special Publication of the American Littoral Society, 14: 6467.

GILMORE, R. G., 1993, Reproductive biology of Lamnoid sharks. In: L. S. Demski \& J. P. Wourms (eds.), The reproduction and development of sharks, skates, rays and ratfisjes. Environmental Biology of Fishes, 38(1-3): 95114.

GILMORE, R. G., DODRILL, F. \& LINLEY, P., 1983, Reproduction and embryonic development of the sand tiger shark, Odontaspis taurus (Rafinesque). Fishery Bulletin, 81: 201-225.

GUBANOV, Y. P., 1978, The reproduction of some species of pelagic sharks from the equatorial zone of the Indian Ocean, Journal of Ichthyology, 18(4-6): 781-792. 
HAMLETT, W. C., 1983, Maternal-fetal relations in elasmobranch fishes. Ph.D. Dissertation, Clemson, Clemson University, 228p.

HOLDEN, M. J., 1974, Problems in the rational exploitation of Elasmobranch populations and some suggested solutions. In: F. R. Harden-Jones (ed.), Sea fisheries research, John Wiley and Sons, pp. 117-137.

OTAKE, T., 1990, Classification of reproductive modes in sharks with comments on female reproductive tissues and structures. In: H. L. Pratt Jr., S. H. Gruber \& T. Taniuchi (eds.), U.S. Dep. Commer., pp. 111-130 (NOAA Technical Report NMFS90).

PRATT, H. L., Jr. \& CASEY, J. G., 1990, Shark reproductive strategies as a limiting factor in directed fisheries, with a review of Holden's Method of estimating growthparameters. In: H. L. Pratt Jr., S. H. Gruber \& T. Taniuchi (eds.), U.S. Dep. Commer, pp. 97-109 (NOAA Technical Report NMFS90).

SANZO, L., 1912, Embrione di Carcharodon rondoletti M. Hle. con particolare disposizione del sacco vitellino. Rendiconti Comitato Talassografico Italiano. Memoria, 11: 3-9.
SMITH, J. W. \& MERRINER, J. V., 1986, Observations on the reproductive biology of the cownose ray, Rhinoptera bonasus. In: Chesapeake Bay (USA). U. S. National Marine Fisheries Service Fishery Bulletin, 84(4): 871-878.

SOKAL, R. R. \& ROHLF, F. J., 1996, Biometria: principios y métodos estadísticos en la investigación biológica. $\mathrm{H}$. Blume Ediciones, Madrid, 832p.

STEVENS, J. D., 1983, Observations on reproduction in the shortfin mako, Isurus oxyrinchus. COPEIA, 1: p. 126130 .

SWENANDER, G., 1907, Über die Ernährung des Embryos der Lamna cornubica. Zoologiska Studier Tillägn T. Tullberg, Uppsala, pp. 283-288.

TESHIMA, K., 1981, Studies on the reproduction of japanese smooth dogfishes, Mustelus manazo, and M. grriseus. Journal of Shimonoseki University Fisheries, 29: 113199.

UCHIDA, S., YASUZUMI, F., TODA, M. \& OKURA, N., 1987, On the observations of reproduction in Carcharodon carcharias and Isurus oxyrinchus. Report of Japanese Group for Elasmobranch Studies, 24: 5-6. 